WSRC-STI-2007-00554

Revision 0

\title{
CHARACTERIZATION OF TANK 50 SLURRY FOR SALTSTONE WASTE ACCEPTANCE CRITERIA, APRIL 2007 SAMPLES
}

Kristine E. Zeigler

Ned E. Bibler

David P. DiPrete

November 2007 


\section{DISCLAIMER}

This report was prepared by Washington Savannah River Company (WSRC) for the United States Department of Energy under Contract No. DE-AC09-96SR18500 and is an account of work performed under that contract. Neither the United States Department of Energy, nor WSRC, nor any of their employees makes any warranty, expressed or implied, or assumes any legal liability or responsibility for the accuracy, completeness, or usefulness, of any information, apparatus, or product or process disclosed herein or represents that its use will not infringe privately owned rights. Reference herein to any specific commercial product, process, or service by trademark, name, manufacturer or otherwise does not necessarily constitute or imply endorsement, recommendation, or favoring of same by WSRC or by the United States Government or any agency thereof. The views and opinions of the authors expressed herein do not necessarily state or reflect those of the United States Government or any agency thereof.

\section{Printed in the United States of America}

Prepared For

U.S. Department of Energy 
WSRC-STI-2007-00554

Revision 0

Key Words:

Tank 50

Waste Acceptance Criteria (WAC)

Saltstone

Retention: Permanent

\section{CHARACTERIZATION OF TANK 50 SLURRY FOR SALTSTONE WASTE ACCEPTANCE CRITERIA, APRIL 2007 SAMPLES}

Kristine E. Zeigler

Ned E. Bibler

David P. DiPrete

November 2007
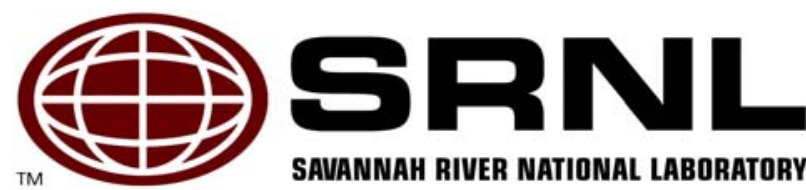
WSRC-STI-2007-00554

Revision 0

\section{REVIEWS AND APPROVALS}

AUTHORS:

TECHNICAL REVIEWER:

APPROVERS: 


\section{EXECUTIVE SUMMARY}

This report summarizes the results from the characterization of the second quarter April 2007 sampling of Tank $50 \mathrm{H}$ for the Saltstone Waste Acceptance Criteria (WAC). ${ }^{*}$ Six one liter samples were taken in polyethylene bottles to analyze for the WAC contaminants and a $200 \mathrm{~mL}$ sample was taken in a steel container for analysis of volatile organic compounds. The information from this characterization will be given to Waste Solidification Engineering personnel to qualify the transfer of aqueous waste to the Saltstone Facility.

The following conclusions are drawn from the analytical results found in this report:

- All six of the one liter samples taken in April 2007 from the mixed slurry in Tank 50 have the same compositions within the experimental uncertainty of the analyses.

- Of the ninety-one process, chemical, and radioactive WAC target or limit contaminants listed in Revision 7 of the "Waste Acceptance Criteria for Aqueous Waste sent to the Z-Area Saltstone Production Facility," eighty-nine had concentrations that were unequivocally less than the WAC limit or target.

- The two contaminants whose concentrations could not be shown to be less than their WAC targets were methanol and radioactive Nb-93m. Currently the AD Section of SRNL does not have a method for measuring methanol in caustic solutions. For Nb-93m the results are ambiguous due to possible interferences in the ICP-MS analysis from Zr-93 or Mo-93.

- Of the six additional chemical and radioactive contaminants requested in the TTR for Saltstone qualification, five were measured or calculated. These were $\mathrm{Sb}, \mathrm{Be}, \mathrm{Tl}$, along with total beta and gamma. The AD Section does not have a method to measure the 6th contaminant which was the cyanide ion.

* Culbertson, B. H., Waste Acceptance Criteria for Aqueous Waste Sent to the Z-Area Saltstone Production Facility (U), X-SD-Z-00001, Revision 7, February 2007. 


\section{TABLE OF CONTENTS}

EXECUTIVE SUMMARY iv

LIST OF FIGURES Vi

LIST OF TABLES vi

LIST OF ACRONYMS vii

1.0 INTRODUCTION AND BACKGROUND 1

2.0 EXPERIMENTAL 3

2.1 Sampling Sequence for April WAC Samples from Tank 50

2.2 Initial Analyses to Determine If the Six Samples Were Identical in Composition 4

2.3 Supernate Analyses $\quad 7$

2.4 Slurry Analyses $\quad 7$

2.4.1 Radioactive Analyses Involving Special Separations 7

2.4.2 Analyses of Aqua Regia Dissolved Slurry Samples 7

3.0 RESULTS 9

3.1 Estimate of the Mo-93 Concentration 9

3.2 Estimate of the Nb-93m Concentration $\quad 10$

3.3 Estimate of the Cs-135 Concentration 11

3.4 Estimate of the Th-229 and Th-230 Concentration 11

3.5 Tables of Results 12

3.5.1 Table $3.2 \quad 12$

3.5.2 Table $3.3 \quad 13$

$\begin{array}{ll}\text { 3.5.3 Table } 3.4 & 14\end{array}$

3.5.4 Table $3.5 \quad 15$

$\begin{array}{ll}\text { 3.5.5 Table } 3.6 & 17\end{array}$

3.5.6 Table 3.7 17

$\begin{array}{ll}\text { 4.0 CONCLUSIONS } & 19\end{array}$

5.0 RECOMMENDATIONS 21

6.0 REFERENCES 23

7.0 ACKNOWLEDGEMENTS 25

APPENDIX 1 


\section{LIST OF FIGURES}

Figure 2-1. Six 1 liter samples from Tank 50, in the order that they were taken. 4

\section{LIST OF TABLES}

Table 2-1. Time Sampled, Volumes, and Personnel Dose Rates for the Seven Samples Taken

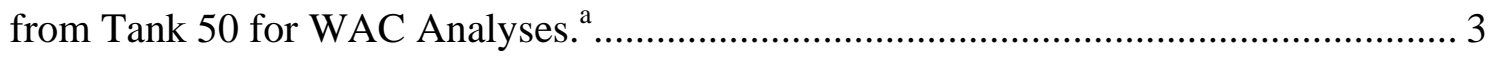

Table 2-2. Initial Gamma Scan Results for the Six Tank 50 Samples.................................. 5

Table 2-3. Densities of the Supernates and Slurries and Weight Percent Solids of the Six 1

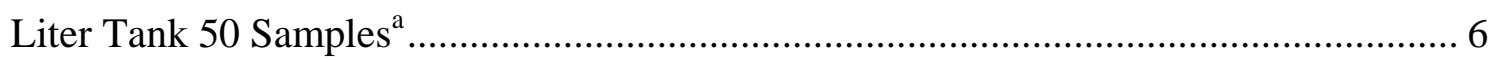

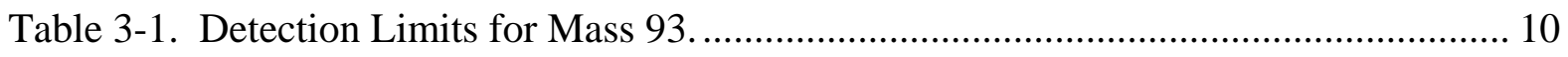

Table 3-2. Results for April 2007 Tank 50 Slurry Samples for Chemical Contaminants Listed in Attachment 8.1 of the Saltstone WAC, Revision 7 ............................................... 12

Table 3-3. Results for April 2007 Tank 50 Slurry Samples for Chemical Contaminants Listed in Attachment 8.2 of the Saltstone WAC, Revision 7 ....................................... 13

Table 3-4. Results for April 2007 Tank 50 Slurry Samples for Radioactive Contaminants Listed in Attachment 8.3 of the Saltstone WAC, Revision 7. .................................... 14

Table 3-5. Results for April 2007 Tank 50 Slurry Samples for Radioactive Contaminants Listed in Attachment 8.4 of the Saltstone WAC, Revision 7. ..................................... 15

Table 3-6. Results for April Tank 50 Slurry Samples for the Saltstone Processing Criteria WAC Limits, Listed in Table 4 of the Saltstone WAC, Revision 7 ............................. 17 Table 3-7. Requests from the TTR for April 2007 Tank 50 Slurry Samples Not Found in the WAC. 17 


\section{LIST OF ACRONYMS}

$\begin{array}{ll}\text { AA } & \text { Atomic absorption (spectroscopy) } \\ \text { AD } & \text { Analytical Development } \\ \text { EDX } & \text { Energy dispersive x-ray } \\ \text { ETP } & \text { Effluent Treatment Project } \\ \text { HLW } & \text { High level waste } \\ \text { HPLC } & \text { High Performance Liquid Chromatography } \\ \text { IC } & \text { Ion chromatography } \\ \text { ICP } & \text { Inductively coupled plasma (spectroscopy) } \\ \text { ICP-ES } & \text { Inductively coupled plasma - (atomic) emission spectroscopy } \\ \text { ICP-MS } & \text { Inductively coupled plasma - mass spectroscopy } \\ \text { MDA } & \text { Minimum detectable activity } \\ \text { MDL } & \text { Method detection limit } \\ \text { ND } & \text { Not determined } \\ \text { RSD } & \text { Relative standard deviation } \\ \text { SDF } & \text { Saltstone Disposal Facility } \\ \text { SFT } & \text { Salt Feed Tank } \\ \text { SPF } & \text { Saltstone Production Facility } \\ \text { SRNL } & \text { Savannah River National Laboratory } \\ \text { SVOA } & \text { Semi-volatile organic analysis } \\ \text { TTR } & \text { Technical task request } \\ \text { TIC/TOC } & \text { Total inorganic carbon/total organic carbon } \\ \text { VOA } & \text { Volatile organic analysis } \\ \text { WAC } & \text { Waste Acceptance Criteria } \\ \text { WS } & \text { Waste Solidification }\end{array}$




\subsection{INTRODUCTION AND BACKGROUND}

The Saltstone Facility is designed and permitted to immobilize and dispose of low-level radioactive and hazardous liquid waste (salt solution) remaining from the processing of radioactive material at the Savannah River Site. ${ }^{1}$ Low activity wastewater streams from the Effluent Treatment Project (ETP), HCanyon, and the high level waste (HLW) storage tanks, are stored in Tank $50 \mathrm{H}$ until it can be pumped to the Saltstone Facility for treatment and disposal. Specific waste acceptance criteria (WAC) must be met for the transfer of low-level aqueous waste from Tank $50 \mathrm{H}$ to the Saltstone Facility. ${ }^{1}$ Low level waste which meets the WAC can be transferred, stored and treated in the Saltstone Production Facility (SPF) for subsequent disposal as saltstone in the Saltstone Disposal Facility (SDF). ${ }^{1}$

Waste Solidification (WS) Engineering had requested through a Technical Task Request (TTR) ${ }^{2}$ that the Savannah River National Laboratory (SRNL) measure the concentrations of chemical and radiological constituents listed in the currently approved Saltstone Waste Acceptance Criteria (WAC). ${ }^{1}$ These determinations are needed on a quarterly (chemical constituents) and semi-annual (radionuclide constituents only) basis, or for a new salt batch, as requested by WS Engineering.,

This document describes the results for the samples taken from Tank 50 in April 2007 for the WAC analyses. 
WSRC-STI-2007-00554

Revision 0

This page intentionally left blank. 


\subsection{EXPERIMENTAL}

\subsection{Sampling Sequence for April WAC Samples from Tank 50}

On April 5, 2007, seven slurry samples were taken from Tank 50 for the WAC analyses. Prior to sampling, slurry pumps B-2, B-4, and E-1 were operated for about 10.5 hours to mix the contents of the tank. At 1222, the pump in the sampling riser (B-2) was shut down and four $\sim 1$ liter slurry samples were taken by lowering 1 liter polypropylene bottles to about 12 inches below the surface of the slurry. (The bottles were open when lowered, so it is not possible to say exactly what depth the samples represent.) The first sample (HTF-50-07-45) was taken two minutes after the pump had been shut off. The other three samples (HTF-50-07-43, -41, and -42) were then taken at approximately two minute increments. The bottles were lowered, pulled up, and immediately capped. The pump in the sampling riser (B-2) was then restarted and operated for a little over an hour before it was again shut down and two more 1 liter samples were taken (HTF-50-07-44 and -46) in the same manner as the first four were taken. At the end of the sampling sequence, a $200 \mathrm{~mL}$ sample was taken from the surface of the slurry in a steel bottle specifically for volatile organic analysis. Sampling times, volume, and personnel dose rates were measured at $\mathrm{H}$-area and are given in Table 2-1. All seven samples were sent to SRNL for characterization.

Table 2-1. Time Sampled, Volumes, and Personnel Dose Rates for the Seven Samples Taken from Tank 50 for WAC Analyses. ${ }^{a}$

\begin{tabular}{|c|c|c|c|c|}
\hline Sample Number & Time Sampled & Sample Volume & $\begin{array}{c}\text { Extremity Rate } \\
\text { (mrem/hr) }\end{array}$ & $\begin{array}{c}\text { Rate at 30 cm } \\
\text { (mrem/hr) }\end{array}$ \\
\hline $50-07-45$ & 1224 & $\sim 1$ Liter & 245 & 10 \\
\hline $50-07-43$ & 1226 & $\sim 1$ Liter & 245 & 5 \\
\hline $50-07-41$ & 1229 & $\sim 1$ Liter & 245 & 5 \\
\hline $50-07-42$ & 1232 & $\sim 1$ Liter & 245 & 5 \\
\hline $50-07-44$ & 1344 & $\sim 1$ Liter & 325 & 5 \\
\hline $50-07-46$ & 1347 & $\sim 1$ Liter & 245 & 5 \\
\hline $50-07-47$ & 1351 & $\sim 200 \mathrm{~mL}$ & 20 & 1 \\
\hline
\end{tabular}

${ }^{\mathrm{a}}$ Data furnished by H-area LWO personnel. 


\subsection{Initial Analyses to Determine If the Six Samples Were Similar in Composition}

Figure 2-1 is a picture of the six samples in a radioactive hood at SRNL. The picture was taken immediately after the transportation polyethylene bags had been removed and the samples were placed in the hood.

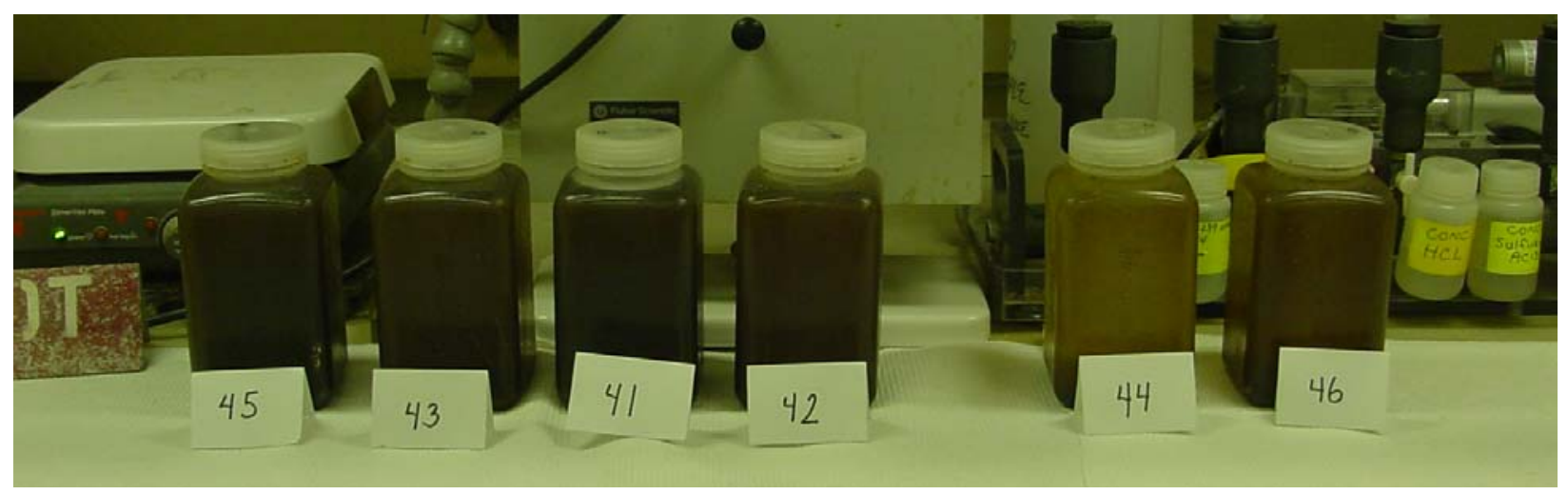

Figure 2-1. Six approximately one liter samples from Tank 50 arranged in the order that they were taken.

All six samples had color to them and all of the samples contained a layer of solids at the bottom. Sample 44 appears to have less solids but it is believed that this sample was not agitated as much as the others when it was removed from the transportation bag. It was then decided that an initial gamma count of an aliquot of each sample would be analyzed as a preliminary determination to see if the compositions were similar. Before sampling, each bottle was shaken vigorously. After shaking, all of the bottles appeared the same. Each aliquot was then counted for 60 minutes. Table 2-2 shows the data from a long gamma count of each of the samples along with their averages, standard deviation, and percent relative standard deviation (\%RSD). 
Table 2-2. Initial Gamma Scan Results for the Six Tank 50 Samples. The Table Contains Individual Counts for Each Primary Gamma Emitter, the Average, Standard Deviation, and Percent Relative Standard Deviation (\%RSD).

\begin{tabular}{|c|c|c|c|c|c|}
\hline Sample & $\begin{array}{c}\mathbf{C o - 6 0} \\
\mathbf{d p m} / \mathbf{m L}\end{array}$ & $\begin{array}{c}\mathbf{S b}-\mathbf{1 2 5} \\
\mathbf{d p m} / \mathbf{m L}\end{array}$ & $\begin{array}{c}\mathbf{C s - 1 3 7} \\
\mathbf{d p m} / \mathbf{m L}\end{array}$ & $\begin{array}{c}\mathbf{E u}-\mathbf{1 5 4} \\
\mathbf{d p m} / \mathbf{m L}\end{array}$ & $\begin{array}{c}\mathbf{A m}-\mathbf{2 4 1} \\
\mathbf{d p m} / \mathbf{m L}\end{array}$ \\
\hline $\mathbf{5 0 - 0 7 - 4 5}$ & $1.70 \mathrm{E}+02$ & $2.24 \mathrm{E}+05$ & $1.28 \mathrm{E}+06$ & $5.32 \mathrm{E}+03$ & $1.43 \mathrm{E}+04$ \\
\hline $\mathbf{5 0 - 0 7 - 4 3}$ & $1.61 \mathrm{E}+02$ & $2.45 \mathrm{E}+05$ & $1.32 \mathrm{E}+06$ & $6.64 \mathrm{E}+03$ & $1.53 \mathrm{E}+04$ \\
\hline $\mathbf{5 0 - 0 7 - 4 1}$ & $1.55 \mathrm{E}+02$ & $2.28 \mathrm{E}+05$ & $1.26 \mathrm{E}+06$ & $5.94 \mathrm{E}+03$ & $1.45 \mathrm{E}+04$ \\
\hline $\mathbf{5 0 - 0 7 - 4 2}$ & $1.70 \mathrm{E}+02$ & $2.38 \mathrm{E}+05$ & $1.32 \mathrm{E}+06$ & $6.27 \mathrm{E}+03$ & $1.33 \mathrm{E}+04$ \\
\hline $\mathbf{5 0 - 0 7 - 4 4}$ & $1.59 \mathrm{E}+02$ & $2.24 \mathrm{E}+05$ & $1.25 \mathrm{E}+06$ & $5.82 \mathrm{E}+03$ & $1.21 \mathrm{E}+04$ \\
\hline $\mathbf{5 0 - 0 7 - 4 6}$ & $1.55 \mathrm{E}+02$ & $2.25 \mathrm{E}+05$ & $1.28 \mathrm{E}+06$ & $5.61 \mathrm{E}+03$ & $1.40 \mathrm{E}+04$ \\
\hline Average & $1.62 \mathrm{E}+02$ & $2.31 \mathrm{E}+05$ & $1.29 \mathrm{E}+06$ & $6.00 \mathrm{E}+03$ & $1.39 \mathrm{E}+04$ \\
\hline Std Dev & $6.86 \mathrm{E}+00$ & $8.80 \mathrm{E}+03$ & $2.95 \mathrm{E}+04$ & $4.95 \mathrm{E}+02$ & $1.10 \mathrm{E}+03$ \\
\hline \%RSD & 4.23 & 3.81 & 2.29 & 8.25 & 7.91 \\
\hline
\end{tabular}

Because the slurries are caustic, all of the radionuclides in Table 2-2, except Cs-137, are insoluble and are primarily in the solids of the slurry. The Cs-137 is primarily in the aqueous fraction of the slurries. Consequently the data in Table 2-2 represent both the solids and the supernate. Based on the average concentration for each radionuclide, it appears that within an experimental error of 2 to $8 \%$, the samples have similar compositions.

Three other physical confirmations indicating that these samples were similiar included the data obtained by measurement of the densities, weight percent total solids in the slurries and the weight percent dissolved or soluble solids in the supernates of the six samples. The weight percent insoluble solids was calculated from the following equation:

$W_{i s}=\frac{W_{t s}-W_{d s}}{100-W_{d s}} \cdot 100$

where

$\boldsymbol{W}_{\text {is }}=$ weight percent insoluble solids in the slurry

$W_{t s}=$ weight percent total dried solids in the slurry

$\boldsymbol{w}_{\boldsymbol{d s}}=$ weight percent dissolved solids in the supernate 
These measurements were performed by Erich Hansen of the Process Science and Engineering Section of SRNL. Table 2-3 shows the results for the six different samples, along with their densities, weight percent total, weight percent dissolved, and weight percent insoluble solids. Details of the measurements will be reported in another document. ${ }^{5}$

Table 2-3. Densities of the Supernates and Slurries and Weight Percent Solids of the Six Tank 50 Samples ${ }^{\mathrm{a}}$

\begin{tabular}{|c|c|c|c|c|c|}
\hline Sample & $\begin{array}{l}\text { Supernate Density } \\
\left(\mathrm{g} / \mathrm{cm}^{3}\right)\end{array}$ & $\begin{array}{l}\text { Slurry Density } \\
\left(\mathbf{g} / \mathbf{c m}^{3}\right)\end{array}$ & $\begin{array}{l}\text { Wt \% Total } \\
\text { Solids }\end{array}$ & $\begin{array}{l}\text { Wt \% Dissolved } \\
\text { Solids }\end{array}$ & $\begin{array}{c}\text { Wt \% Insoluble } \\
\text { Solids }\end{array}$ \\
\hline $50-07-41$ & 1.2489 & 1.2514 & 30.32 & 29.93 & 0.555 \\
\hline $50-07-42$ & 1.2487 & 1.2524 & 30.37 & 29.98 & 0.557 \\
\hline $50-07-43$ & 1.2475 & 1.2526 & 30.42 & 30.13 & 0.420 \\
\hline $50-07-44$ & 1.2489 & 1.2537 & 30.67 & 30.05 & 0.893 \\
\hline 50-07-45 & 1.2491 & 1.2526 & 30.43 & 30.00 & 0.610 \\
\hline $50-07-46$ & 1.2487 & 1.2520 & 30.48 & 30.08 & 0.569 \\
\hline Average & 1.2486 & 1.2525 & 30.45 & 30.03 & 0.601 \\
\hline Std Dev & 5.75E-04 & 7.64E-04 & $1.22 \mathrm{E}-01$ & 7.15E-02 & 1.57E-01 \\
\hline \%RSD & 4.61E-02 & $6.10 \mathrm{E}-02$ & 3.91E-01 & 2.38E-01 & $2.61 \mathrm{E}+01$ \\
\hline
\end{tabular}

a. Measured by Eric Hansen of PS\&E Section. Details to be published in another report. ${ }^{5}$

b. This is the calculated weight percent insoluble solids on a slurry basis.

The results in Table 2-3 show that all six samples have similar densities for both the supernate and for the slurry within very good precisions of 0.05 to $0.06 \%$, respectively. Also the weight percent total solids and dissolved solids are in good agreement, with precisions of $0.2-0.4 \%$. The wt\% insoluble solids, $0.601 \%$, is less than the $15 \mathrm{wt} \%$ limit for the WAC processing criteria. The \% RSD is high for this measurement, $26 \%$, due to the changes between the smaller numbers of the insoluble solids. These results along with the particle size distribution will be published in a later report. ${ }^{5}$

On the basis of the above data it was decided that subsamples of the various bottles would be representative of the entire six liters of sample for contaminants listed in the WAC. Sampling a one liter bottle rather than combining the 6 samples to 6 liters, decreased the radiological hazards while working in a radioactive hood. The slurry was thus easier to mix and sample, hazards from spilling were mitigated, and the extremity and whole body exposure rates were smaller. 


\subsection{Supernate Analyses}

For supernate analysis, each sample was shaken vigorously to thoroughly mix up the solids in the supernate. Before the solids could settle, an aliquot was taken and filtered with a 0.45 micron filter to obtain clear supernate. Filtered supernate from sample bottles 50-07-41, -45 and -46 were sent to the AD Ion Chromatography (IC) laboratory for soluble anion analysis and supernates from bottles 50-07-43, -45 and -46, using the same above procedure, were sent to the AD Wet Chemistry laboratory for hydroxide analysis. Supernate samples from bottles $50-07-41,-42$ and -44 were also sent to the AD Organic Analysis Laboratory for high pressure liquid chromatography (HPLC) analysis of tetraphenlyborate and other nonvolatile organic contaminants. Supernate from sample bottles 50-07-42, -43, and -44 were also sent to Inductively Coupled Plasma-Mass Spectrometer (ICP-MS) for analysis. The sample from the steel bottle (bottle 50-07-47) had been sent for analysis of various organic contaminants by semi volatile and volatile organic analysis (SVOA and VOA, respectively).

\subsection{Slurry Analyses}

\subsubsection{Radioactive Analyses Involving Special Separations}

Slurry samples ( $\sim 150 \mathrm{~mL}$ ) from bottles $50-07-41,-44$, and -45 were submitted to the Radiochemistry group of $\mathrm{AD}$ to perform analyses for most of the radioactive contaminants. The following approved analytical methods were requested: Tritium, C-14, Ni-59/Ni-63, Sr-90, Tc-99, I-129, Gamma Scan, Gamma Scan Cs removed, Pu238/241, Liquid Scintillation Counting, Se-79, Pm-147/151, Am/Cm, and U-232. Samples were digested according to the procedures for the various methods used. For more information on the different techniques, the reader is directed to the AD procedures found in Manual L16, or to the summaries of the methods published in Reference 6.

\subsubsection{Analyses of Aqua Regia Dissolved Slurry Samples}

Duplicate aliquots of the mixed slurry from bottle 50-07-41 were taken for analysis of the remaining radioactive and nonradioactive contaminants. The slurry samples were digested in a radioactive hood by $\mathrm{AD}$ personnel using the aqua regia method to dissolve all the solids.

Bottle 50-07-41 was shaken vigorously before two samples of slurry were obtained. The sample was poured into a preweighed Teflon vessel capable of sealing with a screw cap to hold pressures of $\sim 150$ psia. The exact weight of the slurry in each vessel was, 22.9503 and 28.3031 grams. This slurry amount was used based on the fact that the aqua regia digestion calls for 0.25 grams of solids to be used. (However, it was thought that this larger amount of slurry would be needed in order to obtain enough total solids for the digestion.) These samples were each mixed with $9 \mathrm{~mL}$ of concentrated $\mathrm{HCl}$ acid and $3 \mathrm{~mL}$ of concentrated $\mathrm{HNO}_{3}$ acid and capped immediately to tightly seal the vessels. The vessels were then heated for 2 hours in a $110^{\circ} \mathrm{C}$ oven and after the vessels had cooled, they were opened and each digestion solution was diluted to exactly $50 \mathrm{~mL}$ using DI water. Each sample contained a slight amount of very fine undissolved solids. The solutions were filtered through a 0.2 micron filter to collect the solids. In both cases, the filters were stained with a slight brown color. On the first filter, $1.4 \mathrm{mg}$ of solids were collected and on the other, $1.8 \mathrm{mg}$ of solids were collected. This represents $0.82 \%$ and $1.3 \%$ of solids not dissolved. These fractions are small therefore the consequences of having some undissolved solids is small. It thus appeared that certainly most of the solids in each sample had dissolved. Aliquots of the filtrate were submitted for inductively coupled plasma-(atomic) emission spectroscopy (ICP-ES), ICPMS, atomic absorption spectroscopy (AA) for $\mathrm{Hg}$, As, and Se, Sr-90, and liquid scintillation counting for total beta. 
WSRC-STI-2007-00554

Revision 0

This page intentionally left blank. 


\subsection{RESULTS}

The results for the concentrations of the radioactive and nonradioactive contaminants in the April 2007 Tank 50 samples are given in the following five tables (Table 3-2 through Table 3-6). The first four tables and contaminants are presented in the same order as they are in attachments 8.1 to 8.4 of Revision 7 of the WAC. ${ }^{1}$ The fifth table, Table 3-6, the table of processing requirements, is found in the WAC as Table 4. The order of these tables was done to facilitate transmittal of the results to both the customer and regulatory agencies. Each table provides the method for determination of the concentration of the contaminant, the average concentration (in the appropriate units) based on triplicate or duplicate samples of the slurry (or supernate), the \%RSD of the average, and finally the WAC target or limit for the concentration of the contaminant. WAC limits are imposed to those chemical and radionuclide contaminants listed in Table 3-2, Table 3-4, and Table 3-6. There will be an adverse impact on repository requirements if these criteria are not met. ${ }^{1}$ The WAC targets seen in Table 3-3 and Table 3-5 are a type of acceptance criteria set as a guideline to protect a limit. Targets are monitored on a confirmatory basis and are used to show compliance with regulatory requirements when sample results/calculations/process knowledge indicate that a significant margin exists between the maximum expected value and the regulatory requirement. ${ }^{1}$

The concentrations of some of the contaminants were too low to be measured by the analytical method being used. In these instances, the method detection limit (MDL) for the analytical method is given as the maximum concentration of that contaminant that might be in the supernate or slurry. For all of the analytical methods except ICP-MS, these detection limits were already calculated by AD for each of the results. For ICP-MS, the values for the MDL for each analyte had to be calculated from the instrument detection limit for that analyte multiplied by the factor by which the sample was diluted in the radioactive hood by the dissolution and also the dilution factor used in the analytical laboratory in order to bring the concentration into the calibration range of the instrument. All maximum concentrations calculated in this manner have a less than symbol $(<)$ in front of them in the tables. In all cases these maximum concentrations were less than the WAC target or limit, indicating that the analytical method was indeed sensitive enough to measure whether the concentration of the contaminant was less than the WAC target or limit.

Methods for direct measurements of six of the WAC contaminants in the Tank 50 salt slurry currently have not been developed by AD. Methanol does not currently have a method and is listed as not determined. The others are the radioactive contaminants Mo-93, Nb-93m, Cs-135, Th-229 and Th-230. Conservative estimates of these concentrations can be made according to the following considerations.

\subsection{Estimate of the Mo-93 Concentration}

The radionuclide Mo-93 may be in the HLW as a fission product from U-235 or the neutron activation product of Mo-92 in Mo containing fuel or target assemblies. Also, four nonradioactive isotopes of molybdenum are present in HLW as products of the fission of U-235 from the SRS reactors when they were operating. All four (Mo-95, Mo-97, Mo-98, and Mo-100) were measured at concentrations on the order of 600 to $700 \mu \mathrm{g} / \mathrm{L}$, depending on their fission yield, by ICP-MS analyses of the digested Tank 50 slurry samples. They were also detected and measured in the filtered supernate samples of the slurry. This indicates that they are soluble in caustic probably as molybdate anions, $\mathrm{MoO}_{4}{ }^{2-}$. In both the supernate and the dissolved slurry samples, no isotope was detected at mass 93. Based on the calibration of the mass spectrometer (with a standard solution of natural Mo) and the dilution of duplicate samples of the Tank 50 slurry dissolved by the aqua regia method, the minimum MDL at mass 93 was $133 \mu \mathrm{g} / \mathrm{L}$. Clearly if the analyte at mass 93 is only Mo-93 or is part of a mixture with Zr-93 or Nb-93m or both, the maximum Mo-93 concentration would have to be $133 \mu \mathrm{g} / \mathrm{L}$ or less. Based on the specific activity of Mo$93(1.10 \mathrm{Ci} / \mathrm{g}){ }^{7}{ }^{7}$ the upper limit for the activity concentration for Mo-93 would then be $<1.46 \mathrm{E}+05$ 
$\mathrm{pCi} / \mathrm{mL}$ which is less than the $1.18 \mathrm{E}+07 \mathrm{WAC}$ Limit.

\subsection{Estimate of the Nb-93m Concentration}

Currently there is no unequivocal way to determine the activity of Nb-93m from the data available. The only data available is the ICP-MS results for the aqua regia dissolutions of the Tank 50 slurry samples. As stated above, no analyte was detected at mass 93 and the MDL was $133 \mu \mathrm{g} / \mathrm{L}$. There are two possible ways this data can be used to give estimates of the maximum activity that may be due to Nb-93m. The first way is based on the fact that the primary source of Nb-93m in SRS HLW is the decay of Zr-93 which is the product of the isobaric beta decay chain of mass 93 from the fission of U-235 with a yield of $6.35 \%{ }^{8}$ Zr-93 decays to Nb-93m $97.5 \%$ of the time and has a half life of $1.53 \mathrm{E}+06$ years. ${ }^{8}$ Nb-93m has a much shorter half life of 13.6 years. ${ }^{7}$ The half life of $\mathrm{Zr}-93$ is $\sim 1 \mathrm{E}+05$ greater than Nb-93m. Because of this large difference in the half lives, the activity of Nb-93m reaches secular equilibrium with $\mathrm{Zr}-93$ and their activity concentrations become equal after about 65 years ( 5 half lives of $\mathrm{Nb}-93 \mathrm{~m}$ ). ${ }^{9}$ An estimate of the maximum activity of $\mathrm{Nb}-93 \mathrm{~m}$ in the Tank 50 slurry can be made by assuming that the minimum MDL at mass 93 is due completely to $\mathrm{Zr}-93$ and not Mo-93. The specific activity of $\mathrm{Zr}-93$ is $2.51 \mathrm{E}-03 \mathrm{Ci} / \mathrm{g}^{7}$; so the maximum activity concentration of $\mathrm{Zr}-93$ that could be in the slurry is $333 \mathrm{pCi} / \mathrm{mL}$. When secular equilibrium is obtained, this is also the maximum activity of Nb-93m that can ever be in the slurry. The value of this activity concentration is a factor of 0.00012 times less than the WAC Target. The basis for this first estimate is that $\mathrm{Nb}-93 \mathrm{~m}$ is insoluble in caustic and thus remains in the sludge solids and does not get to Tank 50. An estimate based on Hanford caustic waste has concluded that $98 \%$ of the $\mathrm{Nb}$ as well as $\mathrm{Zr}$ is insoluble and is in the sludge solids. ${ }^{10}$ The second way to estimate the activity concentration of Nb$93 \mathrm{~m}$ is to assume that all of the mass detected at 93 could indeed be Nb-93m rather than Zr-93 or Mo-93. Based on this, the maximum activity of Nb-93m, with its specific activity of $283 \mathrm{Ci} / \mathrm{g}$, is $3.76 \mathrm{E}+07$ $\mathrm{pCi} / \mathrm{mL}$. This is a factor of 13 times greater than the WAC. It should be noted that if the activity due to $\mathrm{Nb}-93 \mathrm{~m}$ were indeed $3.76 \mathrm{E}+07 \mathrm{pCi} / \mathrm{mL}$, this would make it the highest contributor to the radioactivity of the Tank 50 samples. Table 3-1 below gives the maximum activity concentration that could be due to each of the radionuclides if each were the only radionuclide measured at mass 93 . The WAC targets for Mo-93 and Nb-93m are also given.

Table 3-1. Activities due to Mo-93, Zr-93 and Nb-93m if Each Was the Only Radionuclide Measured at Mass 93.

\begin{tabular}{|c|c|c|c|c|}
\hline Isotope & $\begin{array}{c}\text { MDL } \\
(\boldsymbol{\mu} \mathbf{g} / \mathbf{L})\end{array}$ & $\begin{array}{c}\text { Specific Activity } \\
\mathbf{( C i / g )}\end{array}$ & $\begin{array}{c}\text { Concentration } \\
\text { Detection Limit }(\mathbf{p C i} / \mathbf{m L})\end{array}$ & $\begin{array}{c}\text { WAC Target } \\
\mathbf{( p C i} / \mathbf{m L})\end{array}$ \\
\hline Mo-93 & 133 & $1.10 \mathrm{E}+00$ & $<1.46 \mathrm{E}+05$ & $1.18 \mathrm{E}+07$ \\
\hline Zr-93 & 133 & $2.51 \mathrm{E}-03$ & $<3.33 \mathrm{E}+02$ & None Given \\
\hline Nb-93m & 133 & $2.83 \mathrm{E}+02$ & $<3.76 \mathrm{E}+07$ & $2.85 \mathrm{E}+06$ \\
\hline
\end{tabular}

Thus, it is not possible to determine unequivocally whether the concentration of Nb-93m is lower or higher than the WAC target. Because of this uncertainty in obtaining a measured number for the activity of Nb-93m that may be in Tank 50, it is recommended that efforts be made to make the analysis for $\mathrm{Nb}$ 93m more sensitive either by lowering the ICP-MS detection limit for mass 93 or by isolating the Nb-93m from other radionuclides in the slurry and performing radioactive counting. 


\subsection{Estimate of the Cs-135 Concentration}

The radionuclide Cs-135 is a U-235 fission product that can result from the beta decay of Xe-135 (half life of 9.10 hours $^{7}$ ). For the ICP-MS slurry analysis of the aqua regia dissolution, isotopes of mass 135 were detected at concentrations of 91.4 and $90.1 \mu \mathrm{g} / \mathrm{L}$. To be conservative it was assumed that this was all Cs-135 even though there was evidence that some natural Ba was also present in the dissolved slurry. (Natural Ba has an isotope at mass 135 with an abundance of 6.5\%.) Assuming all the mass at 135 is Cs, the average concentration of Cs-135, with its specific activity of $1.15 \mathrm{E}-03 \mathrm{Ci} / \mathrm{g}^{7}$, then its activity concentration is $104 \mathrm{pCi} / \mathrm{mL}$ which is orders of magnitude below the WAC Target of $1.13 \mathrm{E}+06 \mathrm{pCi} / \mathrm{mL}$.

\subsection{Estimate of the Th-229 and Th-230 Concentration}

The radionuclides Th-229 and Th-230 result in SRS HLW from the alpha decay of U-233 and U-234, respectively. The concentrations of Th-229 and Th-230 are small because of the long half lives of U-233 and U-234, (1.59E+05 and 2.36E+05 years, respectively) and the short age of the SRS HLW ( $<60$ years). In the ICP-MS analysis of the two Tank 50 digested slurry samples, no analytes were detected at masses 229 and 230. The mass spectrometer was not calibrated at these masses, however it was calibrated at mass 232 using a standard solution of Th-232. The MDL at mass 232 was equal to $155 \mu \mathrm{g} / \mathrm{L}$. Because the Th isotopes have identical electronic structures, the MDL for Th-229 and Th-230 were assumed to be equal to that for Th-232. With this MDL, the maximum concentrations of Th-229 and Th-230 in the aqua regia digestion of the aliquots of the slurry were both calculated to be less than $1.91 \mathrm{E}-01 \mu \mathrm{g} / \mathrm{mL}$. Based on the specific activities for Th-229 and Th-230, 2.13E-01 and 2.11E-02 Ci/g ${ }^{7}$, respectively, the concentrations become $3.30 \mathrm{E}+04$ and $3.27 \mathrm{E}+03 \mathrm{pCi} / \mathrm{mL}$, respectively. Both of these are lower than their respective WAC targets. 


\subsection{Tables of Results}

\subsubsection{Table 3.2}

Table 3-2 contains information for the chemical contaminants and their limits listed in Attachment 8.1 of the WAC, revision $7 .^{1}$

Table 3-2. Results for April 2007 Tank 50 Slurry Samples for Chemical Contaminants Listed in Attachment 8.1 of the Saltstone WAC, Revision 7

\begin{tabular}{|c|c|c|c|c|}
\hline Chemical Species & Method & $\frac{\text { Average }}{\text { Concentration }(\mathrm{mg} / \mathrm{L})}$ & $\%$ RSD & $\begin{array}{l}\text { WAC LIMIT } \\
\text { (mg/L) }\end{array}$ \\
\hline Ammonium $\left(\mathrm{NH}_{4}{ }^{+}\right)$ & IC & $<1.00 \mathrm{E}+02^{\mathrm{a}}$ & -- & $7.13 E+03$ \\
\hline Carbonate $\left(\mathrm{CO}_{3}^{-2}\right)$ & TIC & $3.55 \mathrm{E}+03^{\mathrm{a}}$ & 1.62 & $1.45 E+05$ \\
\hline Chloride (Cl') & $\mathrm{IC}$ & $2.71 \mathrm{E}+02^{\mathrm{a}}$ & 10.3 & $9.68 \mathrm{E}+03$ \\
\hline Fluoride (F) & IC & $1.90 \mathrm{E}+01^{\mathrm{a}}$ & 7.44 & $4.94 \mathrm{E}+03$ \\
\hline Free Hydroxide $\left(\mathrm{OH}^{-}\right)$ & Total base & $2.00 \mathrm{E}+04^{\mathrm{a}}$ & 2.60 & 1.91E+05 \\
\hline Nitrate $\left(\mathrm{NO}_{3}^{-}\right)$ & IC & $2.44 \mathrm{E}+05^{\mathrm{a}}$ & 5.91 & $5.29 E+05$ \\
\hline Nitrite $\left(\mathrm{NO}_{2}{ }^{-}\right)$ & IC & $2.48 \mathrm{E}+02^{\mathrm{a}}$ & 1.30 & $2.59 \mathrm{E}+05$ \\
\hline Oxalate $\left(\mathrm{C}_{2} \mathrm{O}_{4}^{-2}\right)$ & IC & $8.27 \mathrm{E}+02^{\mathrm{a}}$ & 2.96 & $3.30 \mathrm{E}+04$ \\
\hline Phosphate $\left(\mathrm{PO}_{4}{ }^{-3}\right)$ & ICP-ES & $2.85 \mathrm{E}+02$ & 1.62 & $3.56 \mathrm{E}+04$ \\
\hline Sulfate $\left(\mathrm{SO}_{4}^{-2}\right)$ & IC & $4.78 \mathrm{E}+02^{\mathrm{a}}$ & 3.27 & $6.89 E+04$ \\
\hline Arsenic (As) & AA & $<6.08 \mathrm{E}-02$ & -- & $7.50 \mathrm{E}+02$ \\
\hline Barium (Ba) & ICP-ES & $1.56 \mathrm{E}+00$ & 0.57 & $7.50 \mathrm{E}+02$ \\
\hline Cadmium (Cd) & ICP-ES & $<3.04 \mathrm{E}-01$ & -- & $3.75 E+02$ \\
\hline Chromium (Cr) & ICP-ES & $1.53 \mathrm{E}+01$ & 0.58 & $1.50 \mathrm{E}+03$ \\
\hline Lead $(\mathrm{Pb})$ & ICP-MS & $1.44 \mathrm{E}+00$ & 12.2 & $7.50 \mathrm{E}+02$ \\
\hline Mercury (Hg) & $\mathrm{AA}$ & $6.83 E+01$ & 0.86 & $3.25 E+02$ \\
\hline Selenium (Se) & AA & $<1.22 \mathrm{E}-01$ & -- & $4.50 \mathrm{E}+02$ \\
\hline Silver $(\mathrm{Ag})$ & ICP-ES & $<7.19 \mathrm{E}-01$ & -- & $7.50 \mathrm{E}+02$ \\
\hline Aluminum (Al) & ICP-ES & $8.50 \mathrm{E}+03$ & 0.10 & $1.41 E+05$ \\
\hline Butanol \& Isobutanol & VOA & $<2.50 \mathrm{E}-01$ & -- & $2.25 E+03$ \\
\hline Isopropanol & VOA & $<2.50 \mathrm{E}-01$ & -- & $2.25 E+03$ \\
\hline Phenol & SVOA & $<1 \mathrm{E}-01$ & -- & $7.50 \mathrm{E}+02$ \\
\hline Total organic carbon & TOC & $4.39 \mathrm{E}+02^{\mathrm{a}}$ & 2.63 & $5.00 \mathrm{E}+03$ \\
\hline $\begin{array}{c}\text { Tetraphenylborate } \\
\text { (TPB) }\end{array}$ & HPLC & $<1.00 \mathrm{E}+00^{\mathrm{a}}$ & -- & $3.00 \mathrm{E}+01$ \\
\hline
\end{tabular}

** All AA and ICP-ES measurements were performed in only duplicates.

a. Only supernate was analyzed

It is noted in Table 3-2, that only duplicate measurements were performed on the slurry for all of the AA and ICP-ES analyses. The lead concentration was measured by summing the concentrations of the MS 206, 207 and 208 isotopes, because this yielded a better result than the ICP-ES value which was at the 
method detection limit. The phosphate concentration was calculated from the ICP-ES using phosphorous and converting it to the phosphate ion. It should also be noted that only filtered supernate was analyzed using the IC, TIC, TOC, and HPLC. (On future samples, HPLC should be given a slurry sample so that it can be extracted for analysis.) Although nitrate did not exceed the WAC limit, it is within 2 times the WAC limit compared with the other constituents and should be monitored in future WAC results. The SVOA method did not detect phenol, although it did detect phthalates at a concentration of $51 \mathrm{mg} / \mathrm{L}$ and branched alkyl benzenes at a concentration of $0.41 \mathrm{mg} / \mathrm{L}$. Phthalates are commonly found in industrial plasticizers while branched alkyl benzenes are characteristically found in scintillation cocktails.

It was requested that lower limits than those of the WAC were needed to support the EPA Toxic Characterization Leaching (TCLP) and Underlying Hazardous Constituent (UHC) work. ${ }^{11}$ The elements requested for lower limit analyses were $\mathrm{As}, \mathrm{Ba}, \mathrm{Cd}, \mathrm{Cr}, \mathrm{Pb}, \mathrm{Hg}$, Se, $\mathrm{Ag}$, benzene and phenol along with $\mathrm{Tl}, \mathrm{Sb}$, and Be. These values and their requested limits are given in Appendix 1. All of the values requested were attainable.

\subsubsection{Table 3.3}

Table 3-3 contains information for the chemical contaminants and their targets listed in Attachment 8.2 of the WAC, revision $7 .^{1}$

Table 3-3. Results for April 2007 Tank 50 Slurry Samples for Chemical Contaminants Listed in Attachment 8.2 of the Saltstone WAC, Revision 7

\begin{tabular}{|c|c|c|c|c|}
\hline Chemical Species & Method & $\begin{array}{c}\text { Average } \\
\text { Concentration (mg/L) }\end{array}$ & $\frac{\text { \% RSD }}{\text { WAC TARGET }}$ & $\begin{array}{c}\text { WA } \\
\text { (mg/L) }\end{array}$ \\
\hline Boron (B) & ICP-ES & $6.24 \mathrm{E}+01$ & 0.28 & $\mathbf{9 . 0 0 E + 0 2}$ \\
\hline Cobalt (Co) & ICP-MS & $<2.99 \mathrm{E}-01$ & -- & $\mathbf{9 . 0 0 E + 0 2}$ \\
\hline Copper (Cu) & ICP-ES & $5.19 \mathrm{E}+00$ & 1.54 & $\mathbf{9 . 0 0 E + 0 2}$ \\
\hline Iron (Fe) & ICP-ES & $3.98 \mathrm{E}+02$ & 1.33 & $\mathbf{6 . 0 0 E + 0 3}$ \\
\hline Potassium (K) & ICP-ES & $2.71 \mathrm{E}+02$ & 0.66 & $\mathbf{3 . 6 7 E + 0 4}$ \\
\hline Lithium (Li) & ICP-ES & $<7.52 \mathrm{E}-01$ & -- & $\mathbf{9 . 0 0 E + 0 2}$ \\
\hline Manganese (Mn) & ICP-ES & $2.92 \mathrm{E}+02$ & 0.30 & $\mathbf{9 . 0 0 E + 0 2}$ \\
\hline Molybdenum (Mo) & ICP-ES & $7.11 \mathrm{E}+00$ & 0.00 & $\mathbf{9 . 0 0 E + 0 2}$ \\
\hline Nickel (Ni) & ICP-ES & $4.33 \mathrm{E}+01$ & 0.82 & $\mathbf{9 . 0 0 E + 0 2}$ \\
\hline Silicon (Si) & ICP-ES & $2.35 \mathrm{E}+02$ & 1.13 & $\mathbf{1 . 2 9 E + 0 4}$ \\
\hline Strontium (Sr) & ICP-ES & $2.10 \mathrm{E}+00$ & 1.27 & $\mathbf{9 . 0 0 E + 0 2}$ \\
\hline Zinc (Zn) & ICP-ES & $2.27 \mathrm{E}+01$ & 1.17 & $\mathbf{9 . 7 5 E + 0 2}$ \\
\hline Benzene & & & & \\
\hline Methanol & VOA & $<2.50 \mathrm{E}-01$ & -- & $\mathbf{3 . 7 5 E + 0 2}$ \\
\hline Toluene & VOA & b & & $\mathbf{2 . 2 5 E + 0 2}$ \\
\hline TributylPhosphate & SVOA & $<1.00 \mathrm{E}-01^{\mathrm{a}}$ & -- & $\mathbf{3 . 0 0 E + 0 2}$ \\
\hline (TBP) & HPLC & $<5.00 \mathrm{E}+01^{\mathrm{a}}$ & -- & $\mathbf{3 . 7 5 E + 0 2}$ \\
\hline EDTA & & & & \\
\hline
\end{tabular}

** All ICP-ES and ICP-MS measurements were performed in only duplicates.

a. Only supernate was analyzed

b. Currently a routine method for detecting this species does not exist in AD.

For Table 3-3, again, all ICP-ES and ICP-MS results are analyzed in duplicate. As per the previous table, only supernate was analyzed by HPLC. The chemical contaminant of concern in Table 3-3 is manganese $(\mathrm{Mn})$. Although it did not exceed the WAC target, it is within 3 times the value. Currently there is no 
$\mathrm{AD}$ method to analyze for methanol and therefore it is listed as not determined in the table.

\subsubsection{Table 3.4}

Table 3-4 contains information for the radioactive contaminants and their limits listed in Attachment 8.3 of the WAC, revision $7 .^{1}$

Table 3-4. Results for April 2007 Tank 50 Slurry Samples for Radioactive Contaminants Listed in Attachment 8.3 of the Saltstone WAC, Revision 7.

\begin{tabular}{|c|c|c|c|c|}
\hline$\underline{\text { Radionuclide }}$ & Method & $\frac{\text { Average }}{\text { Concentration }}$ & \% RSD & $\begin{array}{l}\text { WAC LIMIT } \\
\text { (pCi/m/L) }\end{array}$ \\
\hline Tritium $\left({ }^{3} \mathrm{H}\right)$ & Tritium counting & $<2.00 \mathrm{E}+03^{\mathrm{a}}$ & -- & $5.63 E+05$ \\
\hline Carbon-14 $\left({ }^{14} \mathrm{C}\right)$ & $\begin{array}{l}\text { C-14 Liquid } \\
\text { scintillation }\end{array}$ & $<1.79 \mathrm{E}+01^{\mathrm{a}}$ & -- & 1.13E+05 \\
\hline Nickel-63 $\left({ }^{63} \mathrm{Ni}\right)$ & Ni 59/63 & $2.16 \mathrm{E}+02$ & 19.9 & $1.13 E+05$ \\
\hline Strontium-90 $\left({ }^{90} \mathrm{Sr}\right)$ & $\begin{array}{l}\text { Sr-90 Liquid } \\
\text { scintillation }\end{array}$ & $6.85 E+05$ & 6.28 & $2.25 E+07$ \\
\hline Technetium-99 $\left({ }^{99} \mathrm{Tc}\right)$ & $\begin{array}{l}\text { Tc-99 Liquid } \\
\text { scintillation }\end{array}$ & $5.50 \mathrm{E}+02$ & 1.42 & 4.22E+05 \\
\hline lodine-129 $\left({ }^{129} \mathrm{I}\right)$ & $\begin{array}{c}\text { I-129 } \\
\text { (w/ separation) } \\
\text { Liquid scintillation }\end{array}$ & $<3.64 \mathrm{E}+00^{\mathrm{b}}$ & -- & 1.13E+03 \\
\hline Cesium-137 $\left({ }^{137} \mathrm{Cs}\right)$ & Gamma Scan & $5.89 E+05$ & 3.78 & 4.75E+07 \\
\hline Uranium-233 $\left({ }^{233} \mathrm{U}\right)$ & ICP-MS & $<2.14 \mathrm{E}+02$ & -- & $1.13 E+04$ \\
\hline Uranium-235 $\left({ }^{235} \mathrm{U}\right)$ & ICP-MS & $8.72 \mathrm{E}-01$ & 2.78 & $1.13 E+02$ \\
\hline Plutonium-241 $\left({ }^{241} \mathrm{Pu}\right)$ & $\begin{array}{l}\text { Pu238/241 Liquid } \\
\text { scintillation }\end{array}$ & $2.66 \mathrm{E}+04$ & 15.7 & $8.38 E+05$ \\
\hline Total Alpha & $\begin{array}{l}\text { Rad screen liquid } \\
\text { scintillation }\end{array}$ & $1.09 E+05$ & 5.44 & $2.50 E+05$ \\
\hline
\end{tabular}

** All ICP-MS measurements were performed in only duplicates.

a. Upper limit: activity present but may not be from that isotope

b. MDA: actual concentration below the minimum detectable activity value reported.

In Table 3-4, all samples were analyzed in triplicate except the results from the ICP-MS. The radioactive contaminant of concern from this table is the total alpha. Although it does not exceed the WAC limit, it is within 2 times the value and should be noted. Concentrations listed with a note of (a) indicate that the sample was at the upper limit of the measured concentration. This means that activity was present but may not be from that particular isotope. On the other hand, if the value is (b), it is at the method detection allowance which is the reported value detection limit for that species because no activity was present at that level. 
Revision 0

\subsubsection{Table 3.5}

Table 3-5, found on the next two pages, contains the radioactive contaminants and their targets listed in Attachment 8.4 of the WAC, revision $7 .^{1}$

Table 3-5. Results for April 2007 Tank 50 Slurry Samples for Radioactive Contaminants Listed in Attachment 8.4 of the Saltstone WAC, Revision 7.

\begin{tabular}{|c|c|c|c|c|}
\hline$\underline{\text { Radionuclide }}$ & Method DL & $\frac{\text { Average }}{\text { Concentration }} \frac{\text { (pCi/mL) }}{\text { (p) }}$ & \%RSD & $\begin{array}{l}\text { WAC TARGET } \\
\text { (pCi/mL) }\end{array}$ \\
\hline Cobalt-60 $\left({ }^{60} \mathrm{Co}\right)$ & $\begin{array}{l}\text { Gamma scan } \\
\text { (Cs removed) }\end{array}$ & $8.51 E+01$ & 7.48 & $1.13 E+06$ \\
\hline Nickel-59 $\left({ }^{59} \mathrm{Ni}\right)$ & $\mathrm{Ni59/63}$ & $<1.35 \mathrm{E}+01^{\mathrm{a}}$ & -- & $1.13 E+05$ \\
\hline Selenium-79 $\left({ }^{79} \mathrm{Se}\right)$ & Se79 & $3.28 \mathrm{E}+03$ & 6.06 & $1.90 \mathrm{E}+04$ \\
\hline Niobium-93m ( $\left.{ }^{93 m} \mathrm{Nb}\right)$ & See Text (ICP-MS) & $\begin{array}{c}<3.33 \mathrm{E}+02 \text { to } \\
<3.76 \mathrm{E}+07\end{array}$ & -- & $2.85 E+06$ \\
\hline Niobium-94 $\left({ }^{94} \mathrm{Nb}\right)$ & $\begin{array}{l}\text { Gamma scan } \\
\text { (Cs removed) }\end{array}$ & $<5.77 \mathrm{E}+00^{\mathrm{a}}$ & -- & $1.53 E+04$ \\
\hline Molybdenum-93 $\left({ }^{93} \mathrm{Mo}\right)$ & See Text (ICP-MS) & $<1.46 \mathrm{E}+05$ & -- & $1.18 \mathrm{E}+07$ \\
\hline Ruthenium-106 ( $\left.{ }^{106} \mathrm{Ru}\right)$ & $\begin{array}{l}\text { Gamma scan } \\
\text { (Cs removed) }\end{array}$ & $<4.86 \mathrm{E}+01^{\mathrm{a}}$ & -- & $1.13 E+06$ \\
\hline Antimony-125 $\left({ }^{125} \mathrm{Sb}\right)$ & $\begin{array}{l}\text { Gamma scan } \\
\text { (Cs removed) }\end{array}$ & $1.22 \mathrm{E}+05$ & 38.0 & $2.25 E+06$ \\
\hline Tin-126 ( $\left.{ }^{126} \mathrm{Sn}\right)$ & $\begin{array}{l}\text { Gamma scan } \\
\text { (Cs removed) }\end{array}$ & $<3.89 \mathrm{E}+01^{\mathrm{a}}$ & -- & $1.80 \mathrm{E}+04$ \\
\hline Cesium-134 $\left({ }^{134} \mathrm{Cs}\right)$ & Gamma Scan & $<2.14 \mathrm{E}+01^{\mathrm{e}}$ & -- & $1.13 E+06$ \\
\hline Cesium-135 ( $\left.{ }^{135} \mathrm{Cs}\right)$ & See Text (ICP-MS) & $1.04 \mathrm{E}+02^{\mathrm{b}}$ & 1.26 & 1.13E+06 \\
\hline Cerium-144 $\left({ }^{144} \mathrm{Ce}\right)$ & $\begin{array}{l}\text { Gamma scan } \\
\text { (Cs removed) }\end{array}$ & $<1.00 \mathrm{E}+02^{\mathrm{a}}$ & -- & $1.13 E+05$ \\
\hline Promethium-147 ( $\left.{ }^{147} \mathrm{Pm}\right)$ & $\begin{array}{c}\text { Pm147/Sm151 } \\
\text { Liquid scintillation }\end{array}$ & $8.42 E+03$ & 6.42 & $5.63 E+06$ \\
\hline Samarium-151 $\left({ }^{151} \mathrm{Sm}\right)$ & $\begin{array}{l}\text { Pm147/Sm151 } \\
\text { Liquid scintillation }\end{array}$ & $4.18 \mathrm{E}+03$ & 6.41 & $2.25 E+04$ \\
\hline Europium-154 $\left({ }^{154} \mathrm{Eu}\right)$ & $\begin{array}{l}\text { Gamma scan } \\
\text { (Cs removed) }\end{array}$ & $3.99 \mathrm{E}+03$ & 28.7 & $2.25 E+06$ \\
\hline Europium-155 ( $\left.{ }^{155} \mathrm{Eu}\right)$ & $\begin{array}{l}\text { Gamma scan } \\
\text { (Cs removed) }\end{array}$ & $<7.79 \mathrm{E}+02^{\mathrm{a}}$ & -- & $1.13 E+04$ \\
\hline Radium-226 $\left({ }^{226} \mathrm{Ra}\right)$ & $\begin{array}{l}\text { Gamma scan } \\
\text { (Cs removed) }\end{array}$ & $<3.27 \mathrm{E}+02^{\mathrm{a}}$ & -- & $7.97 \mathrm{E}+03$ \\
\hline
\end{tabular}

** All ICP-MS measurements were performed in only duplicates.

a. MDA: actual concentration below the minimum detectable activity value reported

b. assumed all mass 135 was Cs

c. Data for Pu 239 and Pu 240 was the Pu 239/240 data but neither value exceeded WAC target

d. assumed all mass 244 was $\mathrm{Pu}$

e. Aqua Regia digested slurry results used 
Table 3.5 (continued). Results for April 2007 Tank 50 Slurry Samples for Radioactive Contaminants Listed in Attachment 8.4 of the Saltstone WAC, Revision 7.

\begin{tabular}{|c|c|c|c|c|}
\hline Radionuclide & Method DL & $\frac{\text { Average }}{\text { Concentration }} \frac{\text { (pCi/mL) }}{\text { (pCima }}$ & \%RSD & $\begin{array}{l}\text { WAC TARGET } \\
(\text { pCi/mL) }\end{array}$ \\
\hline Thorium-229 ( $\left.{ }^{229} \mathrm{Th}\right)$ & See Text (ICP-MS) & $<3.30 \mathrm{E}+04$ & -- & $1.63 \mathrm{E}+05$ \\
\hline Thorium-230 ( $\left.{ }^{230} \mathrm{Th}\right)$ & See Text(ICP-MS) & $<3.27 \mathrm{E}+03$ & -- & $6.26 E+03$ \\
\hline Thorium-232 ( $\left.{ }^{232} \mathrm{Th}\right)$ & ICP-MS & $<1.70 \mathrm{E}-02$ & -- & $2.88 E+03$ \\
\hline Uranium-232 $\left({ }^{232} \mathrm{U}\right)$ & U232 & 4.41E-01 & 47.0 & $1.71 \mathrm{E}+05$ \\
\hline Uranium-234 $\left({ }^{234} \mathrm{U}\right)$ & ICP-MS & $<1.38 \mathrm{E}+02$ & -- & $1.13 E+04$ \\
\hline Uranium-236 $\left({ }^{236} \mathrm{U}\right)$ & ICP-MS & $6.37 \mathrm{E}+00$ & 5.83 & 1.13E+04 \\
\hline Uranium-238 $\left({ }^{238} \mathrm{U}\right)$ & ICP-MS & $3.19 \mathrm{E}+00$ & 5.6E-01 & 1.13E+04 \\
\hline Neptunium-237 ( $\left.{ }^{237} \mathrm{~Np}\right)$ & ICP-MS & $<1.56 \mathrm{E}+01$ & -- & $2.50 \mathrm{E}+05$ \\
\hline Plutonium-238 $\left({ }^{238} \mathrm{Pu}\right)$ & $\begin{array}{c}\text { Pu238/241 } \\
\text { Pu alpha PHA }\end{array}$ & $7.30 \mathrm{E}+04$ & 21.0 & $2.50 \mathrm{E}+05$ \\
\hline Plutonium-239 ( $\left.{ }^{239} \mathrm{Pu}\right)$ & $\begin{array}{c}\text { Pu238/241 } \\
\text { Pu alpha PHA }\end{array}$ & $4.67 \mathrm{E}+03^{\mathrm{C}}$ & 18.0 & $2.50 \mathrm{E}+05$ \\
\hline Plutonium-240 $\left({ }^{240} \mathrm{Pu}\right)$ & $\begin{array}{c}\text { Pu238/241 } \\
\text { Pu alpha PHA }\end{array}$ & $4.67 \mathrm{E}+03^{\mathrm{C}}$ & 18.0 & $2.50 \mathrm{E}+05$ \\
\hline Plutonium-242 ( $\left.{ }^{242} \mathrm{Pu}\right)$ & ICP-MS & $<8.45 \mathrm{E}+01$ & -- & $2.50 \mathrm{E}+05$ \\
\hline Plutonium-244 $\left({ }^{244} \mathrm{Pu}\right)$ & ICP-MS & $<3.92 \mathrm{E}-01^{\mathrm{d}}$ & -- & $7.02 E+04$ \\
\hline Americium-241 ( $\left.{ }^{241} \mathrm{Am}\right)$ & $\mathrm{Am} / \mathrm{Cm}$ & $9.44 \mathrm{E}+03$ & 29.1 & $2.50 \mathrm{E}+05$ \\
\hline Americium-242m ( $\left.{ }^{242 m} \mathrm{Am}\right)$ & $\mathrm{Am} / \mathrm{Cm}$ & $5.07 \mathrm{E}+00$ & 53.8 & $4.50 \mathrm{E}+05$ \\
\hline Americium-243 ( $\left.{ }^{243} \mathrm{Am}\right)$ & $\mathrm{Am} / \mathrm{Cm}$ & $1.35 \mathrm{E}+02$ & 37.3 & $2.50 \mathrm{E}+05$ \\
\hline Curium-242 $\left({ }^{242} \mathrm{Cm}\right)$ & $\mathrm{Am} / \mathrm{Cm}$ & $4.20 \mathrm{E}+00$ & 54.0 & $1.13 \mathrm{E}+04$ \\
\hline Curium-244 $\left({ }^{244} \mathrm{Cm}\right)$ & $\mathrm{Am} / \mathrm{Cm}$ & $2.25 E+04$ & 38.4 & $2.50 \mathrm{E}+05$ \\
\hline Curium-245 $\left({ }^{245} \mathrm{Cm}\right)$ & $\mathrm{Am} / \mathrm{Cm}$ & $<7.16 \mathrm{E}+01^{\mathrm{a}}$ & -- & $2.25 E+05$ \\
\hline
\end{tabular}

** All ICP-MS measurements were performed in only duplicates.

a. MDA: actual concentration below the minimum detectable activity value reported

b. assumed all mass 135 was Cs

c. Data for Pu 239 and Pu 240 was the Pu 239/240 data but neither value exceeded WAC target

d. assumed all mass 244 was $\mathrm{Pu}$

e. Aqua Regia digested slurry results used

Table 3-5 shows the results of the radioactive contaminants along with their corresponding WAC targets. All ICP-MS measurements were performed in duplicate. For the note (a), the value listed was the MDA for that species. For notes (b) and (d), the masses at those values were assumed to be one isotope. In the case of 135, it was assumed that represented all Cs. In the case of mass 244, that was assumed to be all $\mathrm{Pu}$ (although it was at the MDL for the instrument.) Note (c) tells that the Pu239/240 is given as a total of the mass 239 and 240. For the individual masses, it was the concentration for each, mass 239 and 240, that were determined using the specific activity for the individual isotopes of Pu. In either case, the concentrations did not exceed the WAC limit. Because the Rad Chem lab received both digested slurry and slurry to be digested, some results came back with slightly different numbers. This is the case for Cs134, note (e). In this case, the average of the gamma scan from the aqua regia digested slurry was greater than the other digestion method. The higher value was chosen (even though it is at the method detection limit). 


\subsubsection{Table 3.6}

Table 3-6 shows the processing criteria that must be met in order for the liquid in Tank 50 to be sent to the SPF.

Table 3-6. Results for April Tank 50 Slurry Samples for the Saltstone Processing Criteria WAC Limits, Listed in Table 4 of the Saltstone WAC, Revision 7.

\begin{tabular}{|c|c|c|c|}
\hline Processing Criterion & Method & Value & \%RSD \\
\hline $\mathrm{pH}>10$ & Calculated & $>13$ & -- \\
\hline $3.5 \mathrm{M}<\left[\mathrm{Na}^{+}\right]<7.0 \mathrm{M}$ & ICP-ES & $4.8 \mathrm{M}$ & 0.32 \\
\hline Total Insoluble Solids $<15 \mathrm{wt} \%$ & Calculated & $0.601 \mathrm{wt} \%$ & 26.1 \\
\hline
\end{tabular}

All of the processing criteria fall within the WAC limits. The $\mathrm{pH}$ was calculated from the free base $\left(\mathrm{OH}^{-}\right)$ concentration.

\subsubsection{Table 3.7}

Table 3-7, contains constituents listed in the Technical Task Request, but are not in the WAC. Limits were imposed for some of the elements to aid in supporting the EPA Toxic Characterization Leaching Procedure and Underlying Hazardous Constituent work (TCLP/UHC). ${ }^{10}$

Table 3-7. Requests from the TTR for April 2007 Tank 50 Slurry Samples Not Found in the WAC.

\begin{tabular}{|c|c|c|c|c|}
\hline Constituent & Method & $\begin{array}{c}\text { Average } \\
\text { Concentration }\end{array}$ & \%RSD & Limit \\
\hline Antimony (Sb) & ICP-MS & $3.69 \mathrm{E}-01 \mathrm{mg} / \mathrm{L}$ & 11.4 & $\mathbf{2 3} \mathbf{~ m g} / \mathrm{L}$ \\
\hline Beryllium (Be) & ICP-ES & $<1.59 \mathrm{E}-02 \mathrm{mg} / \mathrm{L}$ & -- & $\mathbf{2 4 . 4} \mathbf{~ m g / L}$ \\
\hline Thallium (TI) & ICP-MS & $4.64 \mathrm{E}-01 \mathrm{mg} / \mathrm{L}$ & 34.4 & $\mathbf{4 . 0} \mathbf{~ m g / L}$ \\
\hline Cyanide (CN) & b. & b. & -- & -- \\
\hline Total Beta & $\begin{array}{c}\text { Liquid Scintillation } \\
\text { Counting }\end{array}$ & $2.23 \mathrm{E}+06^{\mathrm{a}} \mathrm{pCi} / \mathrm{mL}$ & 0.18 & -- \\
\hline Total Gamma & See Text & $7.24 \mathrm{E}+05 \mathrm{pCi} / \mathrm{mL}$ & 7.11 & -- \\
\hline
\end{tabular}

** All ICP-ES and ICP-MS measurements were performed in only duplicates.

a. Aqua Regia digested slurry results used

b. Currently a routine method for detecting this species does no exist in AD.

The ICP-ES and ICP-MS analyses were performed in duplicate. Antimony was calculated by summing the masses of 121 and 123 from the ICP-MS results. This was more sensitive than the ICP-ES results. The total beta count results were from the aqua regia digested slurry as opposed to the digestion used by AD Rad Chem (note a). Currently, no method exists in AD for the detection of cyanide (note b). The total gamma number was calculated by summing the major gamma emitters, Cs-137, Sb-125, Eu-154, and Am-241, from the above tables. 
WSRC-STI-2007-00554

Revision 0

This page intentionally left blank. 


\subsection{CONCLUSIONS}

The analytical results presented in this report support the following conclusions:

- All six of the one liter samples taken in April 2007 from the mixed slurry in Tank 50 have the same compositions within the experimental uncertainty of the analyses.

- Of the ninety-one process, chemical, and radioactive WAC target or limit contaminants listed in Revision 7 of the "Waste Acceptance Criteria for Aqueous Waste sent to the Z-Area Saltstone Production Facility,” eighty-nine had concentrations that were unequivocally less than the WAC limit or target.

- The two contaminants whose concentrations could not be shown to be less than their WAC targets were methanol and radioactive Nb-93m. Currently the AD Section of SRNL does not have a method for measuring methanol in caustic solutions. For Nb-93m the results are ambiguous due to possible interferences in the ICP-MS analysis from Zr-93 or Mo-93.

- Of the six additional chemical and radioactive contaminants requested in the TTR for Saltstone qualification, five were measured or calculated. These were Sb, Be, Tl, along with total beta and gamma. The AD Section does not have a method to measure the 6th contaminant which was the cyanide ion. 
WSRC-STI-2007-00554

Revision 0

This page intentionally left blank. 


\subsection{RECOMMENDATIONS}

For those contaminants whose concentration or concentration maxima are not given in this report (Nb93m, methanol and cyanide), it is recommended that AD Section investigate methods to obtain these concentrations or concentration limits.

The following are the recommended quantities and samples to be used when submitting for routine analytical services to the Analytical Development Section of SRNL for future Tank 50 WAC analyses.

- VOA/SVOA Method- This will be a separate $200 \mathrm{~mL}$ sample taken from Tank 50 in a steel vessel.

- IC anions/cations- Submit this as an undiluted, unfiltered slurry sample, in triplicate, with approximately $10 \mathrm{~mL}$ per sample.

- $\quad$ TIC/TOC Method, Total base/OH/other base - Submit this undiluted, in triplicate, as filtered supernate samples. Submit approximately $20 \mathrm{~mL}$ per sample.

- HPLC Method - Submit this undiluted, in triplicate, as an unfiltered slurry sample. Submit approximately $5 \mathrm{~mL}$ per sample.

- ICP-ES, ICP-MS, AA (Hg, As, Se, K, Na) Methods - Submit these in triplicate as dissolved slurry samples. Nominally dissolve 25 grams of slurry by the standard AD aqua regia method, dilute accordingly, and then filter this solution prior to submitting aliquots to AD. If greater than $10 \%$ of the solids do not dissolve it is recommended that a more rigorous digestion method such as alkali fusion be used.

- Rad Chem Methods - tritium, C-14, Ni59/63, Sr-90, Tc-99, I-129 with separation, gamma scan, $\mathrm{Pu} 238 / 241$, liquid scintillation counting, gamma scan Cs removed, Se-79, Pm147/Sm151, Am/Cm, U-232- Submit this as a slurry sample for rad chem to digest appropriately. Submit approximately $100 \mathrm{~mL}$ per sample of slurry.

It is also recommended that if the radioactive counting analyses need to be more sensitive, a longer count should be requested. For nonradioactive analyses, more sensitive analyses could be obtained by lower dilutions. 
WSRC-STI-2007-00554

Revision 0

This page intentionally left blank. 


\subsection{REFERENCES}

1. Culbertson, B. H., Waste Acceptance Criteria for Aqueous Waste Sent to the Z-Area Saltstone Production Facility (U), X-SD-Z-00001, Revision 7, February 2007.

2. Ray, J. W., Technical Task Request, SSF-TTR-2007-0005, Revision 0, March 2007.

3. Badheka, N. P., Characterization of Tank 50H Sample Waste- 2006, WSRC-TR-2007-00133, Revision 0, June 2007.

4. Oji, L. N., McCollum, S., Characterization of Tank 50H Material Per Saltstone Waste Acceptance Criteria Analysis Requirements-2006, WSRC-TR-2006-00320, Revision 0, October 2006.

5. Hansen. E, Physical Properties of Tank 50, April 2007 Samples, WSRC-STI-2007-00309, Draft 0, May 2007.

6. Bannochie, C. J., and Bibler, N. E., Determination of Reportable Radionuclides for DWPF Sludge Batch 3 (Macro Batch 4), WSRC-TR-2005-00157, Revision 0, April 2005.

7. Integrated Data Base Report-1994: U.S. Spent Nuclear Fuel and Radioactive Waste Inventories, Projections, and Characteristics, DOE/RW-0006, Rev. 11, Oak Ridge National Laboratory, September 1995.

8. Chandler, M. C., Assessment of Niobium in High Level Waste (U), M\&O-2006-0076, October 2006.

9. Friedlander, G., Kennedy, J. W., Macias, E. S., and Miller, J. M. Nuclear and radiochemcistry, $3^{\text {rd }}$ Edition; Wiley \&Sons, Inc.: New York, 1981.

10. Harmsen, R. W. and Shulz, W. W., Best-Basis Estimates of Solubility of Selected Radionuclides in Sludges in Hanford single-Shell Tanks, HNF-3271, Revision 0, October 1998.

11. Zeigler, K. E., and Bibler, N. E., Tank 50 Waste Acceptance Criteria (WAC) Analysis April 2007- Analytical Study Plan, SRNL-ADD-2007-00300, Revision 0, May 2007. 
WSRC-STI-2007-00554

Revision 0

This page intentionally left blank. 


\subsection{ACKNOWLEDGEMENTS}

The authors wish to thank the following people for their assistance and helpful discussions: David Healy, Leigh Brown, Joe Spears, Marti Finney, Tom White, Steve Crump, Robert Ray, Curtis Johnson, Jake Venzie, Mark Jones, CeCi DiPrete, Gina Robbins, Maxine Williams, Kathy Smith. A special thanks to Damon Click, Adrienne Williams, and Rita Sullivan with their assistance and quick digestion of the samples. 


\section{APPENDIX 1. ANALYTES CONCENTRATION AND LIMTS REQUEST FOR THE EPA TOXIC CHARACTERIZATION LEACHING (TCLP) AND UNDERL YING HAZARDOUS CONSTITUENT (UHC) WORK}

It was requested that lower limits than those of the WAC were needed to support the EPA Toxic Characterization Leaching (TCLP) and Underlying Hazardous Constituent (UHC) work.* All of the values requested were attainable.

\begin{tabular}{|c|c|c|c|}
\hline Analyte & Concentration (mg/L) & \%RSD & Limit (mg/L) \\
\hline $\mathrm{Sb}$ & $3.69 \mathrm{E}-01$ & 11.4 & 23 \\
\hline $\mathrm{As}$ & $<6.08 \mathrm{E}-02$ & -- & 100 \\
\hline $\mathrm{Ba}$ & $1.56 \mathrm{E}+00$ & 0.57 & 420 \\
\hline $\mathrm{Be}$ & $<1.59 \mathrm{E}-02$ & -- & 24.4 \\
\hline $\mathrm{Cd}$ & $<3.04 \mathrm{E}-01$ & -- & 2.2 \\
\hline $\mathrm{Cr}$ & $1.53 \mathrm{E}+01$ & 0.58 & 12 \\
\hline $\mathrm{Pb}$ & $1.44 \mathrm{E}+00$ & 12.2 & 15 \\
\hline $\mathrm{Hg}$ & $6.83 \mathrm{E}+01$ & 0.86 & 0.5 \\
\hline $\mathrm{Se}$ & $<1.22 \mathrm{E}-01$ & -- & 114 \\
\hline $\mathrm{Ag}$ & $<7.19 \mathrm{E}-01$ & -- & 2.8 \\
\hline $\mathrm{Tl}$ & $4.64 \mathrm{E}-01$ & 34.4 & 4.0 \\
\hline Benzene & $<2.50 \mathrm{E}-01$ & -- & 10 \\
\hline Phenol & $<1 \mathrm{E}-01$ & -- & 6.2 \\
\hline
\end{tabular}

* Zeigler, K. E., and Bibler, N. E., Tank 50 Waste Acceptance Criteria (WAC) Analysis April 2007Analytical Study Plan, SRNL-ADD-2007-00300, Revision 0, May 2007. 


\section{Distribution:}

J. L. Adams, 704-Z

N. P. Badheka, 773-42A
A. B. Barnes,
999-W

M. J. Barnes,

773-A

S. B. Beck,

704-Z

C. H. Beheler,

704-14Z

S. D. Burke,

704-S

H. H. Burns,

999-W

M. C. Chandler, 703-H

B. H. Culbertson, 704-27S

E. J. Freed, 704-56H

J. C. Griffin, 773-A

E. K. Hansen, 999-W

J. R. Harbour, 999-W

S. D. Heath, 704-Z

C. C. Herman, 999-W

P. J. Hill, 766-H

W. L. Isom, 766-H

C. J. Johnson, 704-14Z

C. A. Langton, 773-43A

K. R. Liner, 704-S

M. J. Mahoney, 766-H

J. E. Marra, 773-A

D. J. Martin, 703-H

C. A. Nash, 773-42A

P. W. Norris, 704-Z

E. Patten, 704-Z

J. W. Ray, 704-S

A. L. Richardson, 704-Z

L. B. Romanowski, 766-H

R. L. Salizzoni, 703-H

D. C. Sherburne, 704-S

A. V. Staub, 704-27S 